Augustyn Bańka*

DOI: $10.2478 /$ v10241-012-0025-3

\title{
Postwar creations of strangers and estrangement: Notes on the ways to recovery and normalization
}

\begin{abstract}
This paper is an attempt at exploring the phenomenon of creation of strangers and estrangement as post-war trauma effects. It starts with an observation that post-war is a mental state manifesting itself in individuals as estrangement from themselves, environment, other people, and from the very meaning of life. The post-war trauma triggers a tendency for recovery and normalization of life, which, however, never ends. The paper focuses mainly on four aspects. Firstly, critical moments of the evolution of post-war periods in Europe are discussed, starting with the end of war until now. Secondly, the evolution of change in mental moral grammar in specific post-war periods is looked upon. Thirdly, paths to recovery and normalization through the creation of strangers and estrangement in consecutive, critical post-war periods are indicated. Lastly, this paper tries to present the paradoxes of all the periods of the post-war syndrome.
\end{abstract}

KEYWORDS: Post-war, estrangement, recovery, normalization

* Correspondence regarding the paper should be sent to: Augustyn Bańka, University of Social Sciences and Humanities (SWPS), Department in Katowice, ul. Kossutha 9, 40-844 Katowice, tel. 3275060 80, e-mail: abanka@swps.edu.pl 


\section{INTRODUCTION}

Wars are an inseparable part of civilization and at a global scale no day passes by without a war being fought, however cruel they may be. As much as people try to avoid armed conflicts, wars will break out and will not end instantaneously but are followed by, what P. Sloterdijk (2009) defined as post-war periods. These are long periods of recovery from the "post-war syndrome" (Tony Judt, 2007), re-achieving mental homeostasis and normalization. Thus, war and the post-war period form one cycle which regrettably ends in another war (Judt, 2007). Moreover, unresolved effects of wars fought in different time periods, overlap, complicating in turn the post-war recovery and normalization processes on an individual, national and international level.

A war outbreak can have a multitude of causes; however one of the most important is always a specific mental syndrome emerging in peoples' minds. A prime example is the outbreak of World War II, which was rooted in resentments caused by how World War I was concluded forming a mental, social and financial construct defined as the "Weimar Syndrome" (Sleoterdijk, 2008). Resentment is one of the post-war and normalization process mechanisms that has been thoroughly defined the earliest, considering its ominous potential. This article aims at presenting psychological mechanisms involved in forming of mental phenomena caused by successive post-war periods that go together with a never ending process of recovery and normalization. The focus of this article is on the post-war creations of strangers and estrangement.

The effects of such total wars as World War II can not only be long lasting, but also have the ability to evolve in successive post-war periods. Each post-war period is a critical moment in the evolution of post-war recovery and normalization. A different moral code as well as a different mental disposition is dominant (Seeman, 1971), which in turn changes the definition of the terms 
"strangers" and "estrangement". As long as the post-war period continues, categories of strangers and estrangement are being formed, however for each phase it is different and the way of identifying these phenomena becomes a sign of recognition for recovery and normalization processes.

WAR AND ITS LEGACY - STRANGERS, ESTRANGEMENT, AND HATE

World War II ended in 1945 but its effects still linger in the minds of most of the people living in Europe to this day. As it will be proven later in the article, psychic effects of the war are passed by to next generations and emotions linked with the memory of war are often times stronger in generations that had no contact with the immediate results of the war. War changes culture and this can be constantly seen in the consciousness seeking identity patterns and meanings that unite people together and with the environment.

People and societies suffering the post-war syndrome are affected by a specific ambiguity, which can be characterized as a constant self-struggle. These societies unknowingly and subconsciously create strangers on one hand and states of estrangement from themselves, other people, their environment and the meaning of their lives on the other.

The reasons for estrangement and creating strangers in modern societies are complex, since they emulate the increasing social entanglement, multitude of choices, development of technology, urbanization and bureaucracy. However the problem of estrangement is deepest in societies that suffered World War II aftermath the most, because it is still an important indicator of normalcy. Post-war syndrome stems from a trauma both experienced and inherited, as well as from an individual and collective place memory. Considering European societies, it needs to be said that they 
have different war experiences and memories, and their need of dealing with it in terms of coherence and the continuity of their own identity is also a matter of individual cases (Judt, 2008)

Polish nation, as very few nations in the world, suffered from extreme and deep psychic wounds inflicted upon it by the war and its aftermath in the years 1944-1947, defined by M. Zaremba (2012) as "The Great Fear". According to the author, this term encompasses not only estrangement, fear, anxiety, trauma, but also anomy mixed with a view of the world without moral boundaries where the difference between crime and mere self-defense is blurred. The Holocaust of the Polish society (Lukas, 2012) did not end with the retreat of the Germans but went on when the Soviets replaced the German military with their own, matching the former occupants' cruelty.

World War II was a conflict between countries and nations, where the sides defined the enemy and stranger from different perspectives. Germans as the main guilty party of war positioned strangers based on resentment, which was supposed to be a memory and became history (Sloterdijk, 2008). Strangers were everyone who in the social German consciousness were guilty of humiliating them after World War I, mainly Jews and Poles. The process of creating strangers through social, cultural and humanitarian estrangement of the perpetrators became epic in scale in the minds of Germans (Sloterdijk, 2009). This process led to creating a false sense of those guilty of all the unhappiness, estranging from not only Jews and Poles, but from most neighbors. Creating strangers and estrangement, affectively, is bound with strong emotions of hostility and hatred.

People from countries like Poland were subject to a physical extermination on a scale unmatched in the history of warfare. From the very outbreak of war, their identity has been defined by pathological hatred. Facing cruelty and dehumanization of their own identity together with physical ghettoization a natural defense reaction is to create strangers and estrangement in their 
own way. For people suffering from terror and genocide, those that inflict such torture become strangers void of humanity, but not only them. Part of the population suffering from war terror was automatically subject to estrangement for being Jews. Some people, as was the case of Poles living in Greater Poland, were being treated as subhumans (untermenschen) and were expelled into General Government - a ghetto of a country scale. Lastly, some people were forced to a decision concerning their national affiliation. For example Silesians and Kashubians could chose between being a second category German in the form of a Volksdeutsch in order to avoid extermination or if they accept their fate as subhumans and future extermination (Kaczmarek, et al. 2012). Part of the Polish population from southern Poland (Podhale) chose the path of voluntary conversion, agreeing to the status of Volksdeutsch, becoming strangers and enemies for their neighbors and family who did not chose the path of treason. (Szatkowski, 2012).

Even though the estrangement of people branded by Germans as enemies was defined in relation with the aggressor, in case of other groups self-estrangement in relation with their own kin was predominant. This phenomenon is defined as self-hating and is an effect of pathologizing dissent inside an own ethnic group, which is a reaction of being a member of a disadvantaged group (Finlay, 2005). Self-hating, the hate of own ethnic group was introduced by Kurt Lewin (1941/1997). Initially this term was used to describe the Jewish populace, but as K. Lewin noted after moving to the USA, self-hating syndrome is a part of other ethnic groups like Poles and Italians. It is a natural reaction to discrimination and conflict (Monteith and Winters, 2002; Robinson, Wilkowski 2006). Nowadays self-hating can be applied to any group or nation, be it Jews and Poles (Segev 2012; Szatkowski 2012), Japanese (Kersten 2009) or Americans (Hollander 1992). World War II launched the self-hating syndrome into new heights on an unimaginable scale, 
where both the perpetrators and victims of Holocaust became the haters.

\section{POST-WAR PERIODS AS TIME OF SELF-REGULATIONS} AND CLEANSING OF CONSCIENCE

According to Tony Judt (2008) post-war period is a time, following the wartime trauma, of self-regulation, where people regain health and normalize their lives. Depending on the country or group this process varies in time, but it follows similar psychological rules of dealing with post-traumatic stress. However, Peter Sloterdijk (2009) states that for self-regulation of culture the post-war period is a process of normalizing social and cultural consciousness deformed by war. It is a time when the process of interpretation of the outcome of war is done by both the defeated and the victors. Building mental justification for the outcome of war is an important factor for the way people view themselves and define what it means to be a victor or a defeated. They both have a tendency for attributing certain facts to being what they are. In post-war Europe these two types of war self-regulations (individual and cultural) sometimes overlap but also sometimes they can be completely different. Even though at the level of individual psychological reactions losses are counted similarly through the measure of suffering and pain, the cultural level is quite different, because it is blurred by the simple controversy of who is the victor and who is the defeated.

In the post-war Europe not all was clear, but the controversy was suppressed by the end-of-war enthusiasm. That is why nobody really discussed on which side of the conflict were countries such as Italy or the Soviet Union. Feelings of the survivors of war and politicians or ideologists, who were observing the great conflict from a safe distance, varied immensely. For instance, in Italy the simple fact of assassinating Mussolini was enough to 
build a false identity claiming Italy was a member of the Allied countries (Oliva, 2006). Whereas in Israel, seven million of the Jewish Holocaust survivors were tagged with the humiliating label "soap" ("sabon" in Hebrew) (Segev 2012).

An example of post-war self-regulation is a cleansing of conscience done "en masse" together with creating justifications for the results of battles. The French and German ways to recovery and normalization are completely different in this aspect. Germans, as those who lost, took a path called by Peter Sloterdijk (2009) "metanoia", but the French victors took a path of "affirmation". "Metanoia" is a process of recovery following defeat in battle, during which a re-evaluation of normative stances take place, which are a part of the "metanoetical" syndrome which was the cause of war. Obviously, in the case of Germans it was the Weimar syndrome which was both the leading cause and result of defeat. "Metanoia" is not only a simple diagnosis of the scope of guilt and responsibility, but also a way of defining "moral grammar" from the perspective of "what's next?". French way of recovery from the war stress was to defuse trauma by "affirmation" and creating justifications as well as freeing the imagination to allow perceiving one as being a victor.

Reinterpretation of the war result inside the German society is defining strangers and estrangement inside their own community. The immediate post-war period prevented from neither displacing guilt nor responsibility on an outside factor nor denying being guilty of the accusations made. This situation, somewhat forced, was for Germans very advantageous, because it redirected energy from the "metanoetical" messianism to rational actions of everyday rebuilding effort. A converse re-positioning process of identity in the re-interpretation of results of war was done by the French. Placed in a far from obvious role of victors during the process of positive war result affirmation they needed to estrange themselves from guilt and seeking strangers in their own community. It resulted in France regaining its former national glory. 
After the war, every nation was faced with the problem of reinterpretation of results of war, but Poles were by far in the worst possible situation. Before the war even ended, having the $4^{\text {th }}$ largest allied army, still they were positioned in a schizophrenic spot of neither victor nor defeated. German occupation was replaced with a Soviet one, whereas the status of a free nation was replaced with a conquered and post-colonial state (Judt 2009; Lukas 2012). The feelings of betrayal, abandonment and having suffered Holocaust together with immeasurable sacrifice prevented the process of self-regulation and cleansing of conscience. The old strangers were replaced by "new strangers", who unexpectedly were "neighbors", former fellows now enemies. Who and how people positioned other people as strangers depended on a given point of view (Gross, 2001; Zaremba 2012). Objective facts and acts had little to do with the truth, because facts were replaced by words (Mannet 2008). The total realignment of criteria of actions resulted in the creation of estrangement in opposition to every possible post-war process: communization, reconciliation, sense of patriotism, sense of decency, good and evil. When a patriot fighting for dignity and survival was deemed a criminal, whereas a criminal was deemed a hero for whom statues were built, normal people had difficulties in finding a meaning of life and war. The sense of betrayal, humiliation and abandonment closed the minds of Poles in a schizophrenic trap, which effects still linger to this day.

\section{POST-WAR STRUGGLE TO REINVENTION OF MENTAL PATTERNS}

Every memory becomes blurry with time and the further we are from the original event, new information comes to surface. War memory is the same, affected by new circumstances, new atmosphere and new surroundings. The first post-war phase of interpreting the results of war is a mental deconstruction of the reality that was the base of the conflict. One important aspect of 
this process is recovery, meaning a way of overcoming emotional and spiritual imbalance that helps with everyday activities as well as reconciliation between nations. Phase two is latent post-war, which is a time of re-interpretation of results of war based not on feelings and memories but on cognitive processes, which are reconstructive and prospective in nature. War images seize to be original events but are replaced with mentally constructed events. Retrospective memory gives way to prospective memory, which means a growing domination of social consciousness obligation. In this new memory of war defining category of strangers starts to be an abstractive measure based not on bivalent logic but on heuristics of fuzzy sets. Categories of "Us and Them" in the fuzzy logic is replaced by fuzzy sets, where a fascist does not have to be an Italian, German a Nazi or a Nazi does not have to be a national socialist. Even though the post-modernistic uncertainty is not to blame for this, but a moral grammar of forgiveness, the fuzzy logic of true and false, good and evil escapes unambiguous categorization giving way to hierarchic categorization.

After achieving a basic level of recovery and normalcy in everyday life, Europe took the next step of reconstruction, which can be described as post-war struggle to reinvention of mental patterns. The memory of the main cause of war, the Weimar syndrome, still strong in the political establishment dictated the redefining of the term post-war homeland. It was acknowledged that in order to prevent such disasters as the World War II from happening again the post-war homeland needs to be merged into a supranational structure of a higher rank. Again, it was also deemed necessary to strengthen European integration in order to overcome conflicts between nations. This is how the idea of "europization" emerged and the first step was creating the European Coal and Steel Community transformed afterwards into European Economic Community.

Categories of strangers and estrangement created during the earlier post-war normalization phase became dysfunctional. In 
this new trend of seeking supranational communities as a guarantee of preventing the comeback of national egoisms, strangers are those who still feel attached to the idea of a nation state and estrangement comes in the form of voluntary self-estrangement from the nation state. Citizen empowerment is conceived as an externally driven, state and transnational process (Bańka \& Ertelt 2011). In this new trend of normalization old categories of an enemy being a fascist or a Nazi become obsolete. Only the motivation of joining the process of europization, as a path to socialization and development counts. That is why the idea of building a united Europe on the grounds of forgiveness was compelling for Christian Democrats, who were always big supporters of united Christianity, but also for socialists, communists and even former national socialists.

Europization as an alternative for the post-war homeland changed former strangers into a quasi-community of a yet to be defined European identity in a meaningful way. Repositioning of the self of the former defeated and victors into a common identity basing it on pragmatic ideas of a common goal was a realistic achievement. A strong national identity in the face of a successful community and mental socialization weakens, giving way to a "common good" ideology. Normal people notice the advantages of a social state and transnational integration making them accept the universalization of European values. European community structures are deemed as friendly, pragmatic and contributing to the overall prosperity and development.

The situation changed when pragmatic integration started to become a political project trying to expand into a European super state. The pragmatic policy of social security slowly gave way to a notion that the states' social sensitivity and European institutions have an almost naturally given law of interfering in the everyday lives of citizens. The thought process of the political establishment and the grassroots started to drift apart. Even though europization as a vision of development through externally guar- 
anteed safety became a common mental pattern of Europeans, growing integration positions the United Europe's bureaucracy in the category of strangers. Building the European prosperity and "new man" starts to be deemed by people as something that is never done and yet, which causes estrangement. People need and grow increasingly dependent on state support and still, they feel alienated and animosity towards the system. Civic participation deteriorates and is replaced by European bureaucracy. The biggest paradox of the post-war phase of growing prosperity is the increase in the number of discontented (Judt 2009). This is caused by new thought currents such as postmodernism or postcommunism (Holladner 2002).

\section{POST-COMMUNISM AND REASSEMBLING OF THE POST-WAR TRANSNATIONAL ORDER}

The project of europization as an opposition to the "American way of life" after the fall of the Soviet Union needed a major reorganization. The fall of the old transnational order being a preserved post-war state shattered the peace, stagnation and vision of development. After the fall of the Iron Curtain, old Europe is finally reassembled with the eastern part of the continent, called the new Europe. For Germany it brought a new task of reuniting the country and turning back from the path of "metanoia" onto the path of "metanoetics". Uniting the country cannot be done without national mental patterns, which clearly are in opposition to the rule of transnational integration. Post-communistic European reality needs a reassembly of the transnational order, which from the German perspective means re-positioning of the self from the abstraction of a pan-European centered dimension to adopt a more egoistic direction defined around a national dimension, homeland. 
Whereas for the European Union, the fall of the Berlin Wall means a new task of managing a new transnational order by defining yet again the borders of Europe. Old notions such as East and West lose their regulatory meaning. The coming modifications of a developed for decades project needs to adjust to a growing number of member states but also the new architecture of the late post-war phase. The policies undertaken by the political establishment are often times improvised, which in turn surprise the old Europe population used to a constant increase in prosperity. Introducing a change such as the Economic and Monetary Union without consulting the general public virtually split Europe in half and furthered the estrangement from bureaucracy, as well as gave way to a new form of alienation such as powerlessness.

The frustration of citizens of old Europe, caused by blocking their empowerment through the increase of European bureaucracy that cripples their sense of authorship became an impulse to treat the new members of the European Union as strangers. To-be-victorious europization as a form of progressing socialization reshaped from an idea of a commonwealth of nations into a commonwealth of governments based increasingly on a national self-estrangement. According to P. Sloterdijk, estrangement becomes a euphemism for normalization (Sloterdijk 2009). Increasingly detached from European societies, the bureaucracy of the European Union is under the impression that it can save the world, whereas normal people start questioning whether the super-state can actually take care of them. This is how overcoming the inheritance of World War II - the Iron Curtain - finally ends in a weird paradox. Normalization, which meant a pragmatic way of non-violent coexistence between nations, transforms after the fall of communism into estrangement from a seemingly assimilated idea of europization. It is the beginning of a breach between various national interests so the European nations once again start following their own paths. 
POST-HISTORICAL MODUS VIVENDI AND EMERGING

OF POLITICAL PARANOIA

Even though the fall of communism was to be the end of history, it is indeed the opposite (Fukuyama 1992). Wars in the past were a matter of affective and military mobilization, however today in the post-historic period they give way to new symbolic wars, where affective symbolic force is mobilized (Illouz 2007). The fall of communism as a beginning of the post-historical modus vivendi introduces unstable, temporary agreements. Having this in mind it introduces a need of conducting new post-war narratives. This need is fueled by a growing sense of fluid integration. Repeating over and over again that the cure for troubles with integration is even more integration sounds increasingly false, that is why the old post-war question arises - "what's next?"

The return of post-war narration after the fall of communism does not surprise because in some countries like Poland accounting for past crimes was blocked in earlier stages of normalization and was enabled just recently. In these new narrations of World War II the same issues appear as during the first years of the post-war period, namely guilt and responsibility, crime and punishment, memory and forgiveness. Once again the victors and defeated, perpetrators and victims voice their opinions. The defeated return to the subject of guilt and punishment in a more reflective and personal way, with an irresistible need of cleansing their conscience, so as to prove Fyodor Dostoyevsky's words that if there's a crime there needs to be a punishment.

For the post-historic narrations of post-war two new circumstances are characteristic. On the subject of results of war new actors start voicing their concerns, who did not experience war at all, however their emotional engagement is so big that it is almost paranoid (Robins i Post 1999), making this period the "golden age of paranoia" (When 2009). The second new circumstance that emerged is postmodernism (Hollander 2002) and the cultural 
changes that came with it, namely therapy culture or celebrity culture (Furedi 2003, 2010). Post-historic re-interpretation of the results of war is characterized with a certain level of chaos, since the modern aims are determined by the confines of sovereignty, integration and globalization. These three goals are in conflict and can never be achieved simultaneously, but discourse dictates that sometimes one of these takes precedent and other times a different one does. Since the War common memory in Europe changes, depending on various critical moments in time. It is a change from the most minimalistic common denominator of war images categorized as "abnormality” to completely divergent images of war being normalcy "backwards". Common memory breaks down into partial and concurrent memories.

A successful European integration during previous post-war stages of normalization when recalled during the post-historic discourse suffers from deformation. Europe always had two paths to the so-called "founding origins" (Brague 1992). One was the path of "cultural loan", meaning an inferiority complex; the other was an autochthonic path, meaning having high self-esteem and knowing the source of an autonomic culture. In the post-historic modus vivendi it is sometimes forgotten that the founding of ECSC was based on an earlier Christian European integration. Christian Democrats played an active role during this time and it was nothing else but taking out a cultural loan. The post-historic integration in the form of the Treaty of Lisbon changes the path of European development to an autochthonic one, which is marked with a feeling of superiority. Superiority complex being an emotion not a fact, manifests itself through the feeling of being superior to the opposition, in this case the source of the feeling itself. It dictated the signers of the Treaty of Lisbon to estrange Christianity from the founding act of European integration, since they could not cope with the fact that they would not be the protagonists of the next steps to normalization. This way, Christians became strangers and were tagged as the main enemies in symbolic warfare. 
Taboo violation in accordance with everything that is sacred for Christians became a sought out element of political correctness. In this setup taboo violation is a versatile tool of blurring the borders between experiencing emotions and creating emotions. Religion is used both to humiliate strangers and to trigger emotions all in the framework of symbolical terror (Harper 2002). Taboo violation is redirected to tradition as a main opposition of progress, taking the form of profanity in art, aggressive language or brutal behavior in everyday human relations. Constructing strangers and estrangement in relation to conservatism and tradition forces the term normalcy into a pathologizing dissent (Finlay, 2005) on one hand and an inversion of the meanings of taboo from the historical period of recovery and normalization processes, on the other.

In the post-historical normalization amending is done to, euphemistically stated by P. Sloterdijk (2009, p. 38), “...Germany's long expected entry into the manifest stage of its normalization whereby one has to admit that this will be, after such long deformation of history, a paradoxical first-time-round normality". This stage of normalization is a way of dealing with history according to the "...assumption, that without inner integral realization there can be no serious involvement of the consciousness in the horrors of German war crimes, forms an essential corrective to the commemorative events seen as a matter of course". The last accord of the post-historical post-war recovery and normalization in the way of "integral realization" leads to a reinterpretation of results of war by inversion of meanings, denying facts and creating other facts. On one hand, defeated on the grounds of the new "therapy culture" (Furedi, 2003) demand the right to the "forgive and forget" rule, on the other though, assume the role of the main victims of war, positioning others as the main guilty party of the tragic results they had to endure or as simply paranoid. In the latter case, P. Sloderdijk's (2009, p.36) remark is symptomatic: "It has won back the trust of its neighbors - if we ignore a few poisoned depots in England and Poland where anti- 
German emotions reproduce anaerobically as were -and there too, where forgiveness is beyond the realms of what is humanly possible, it has evoked a certain respect as to its metamorphosis".

An example of the "forgive and forget" rule as a new way to recovery and normalization immersed in the therapy culture is the confession of Günther Grass (2007) regarding his engagement in Waffen-SS. G.Grass demands that this fact be erased from the category of taboo and repositioned to the category of normalcy. His expectations are in tune with therapy culture since he's a victim of vulnerability caused by having to hide the truth from the crowd, which was unable to forgive. He is of the opinion that this vulnerability be met with common compensation by acknowledging him as a hero. An example of turning around the meaning of war results are the actions of Erika Steinbach from the Federation of Expellees (BdV, Bund der Vertriebenen). The Federation flips the meaning of victors and defeated. From this point of view, Germans are the main victims of war even though facts presented by the latest report of Michele Schwartz from the Institut für Zeitgeschichte in Munich (Jendroszyk, 2012) prove otherwise. This report shows that from the 13 founding members of the Federation 11 of them had a NSDAP or SS identity card. After putting this fact into perspective post-war resolution in Germany turns again to resentment both in the mental reconstruction and cultural sense (Melendy 2006; Macdonald 2009).

In Poland after the fall of communism, normalization was a late effort of re-evaluation of post-war outcomes. Apart from the re-interpretation of World War II itself the debate also extended into discussing the future. Because of this, re-interpretation narrative took the form of an argument between discussing the events of war and post-war (Gross 2001: Zaremba 2012), as well as the role of continuity of tradition (Legutko 2008) in the united and integrating with two-speeds Europe. In this late, Polish, post-war self-discovery the emotional level quickly achieved a self-reinforcing pathologizing dissent. Contrary to Germany, 
where the construction of strangers and estrangement took the path of self-cleansing, in Poland the creation of strangers and estrangement evolved into a growing attribution of blame onto self and the application of the pedagogy of shame (Bartky 1996). Re-interpretation of war and post-war in categories of moral responsibility re-positioned the Polish self into categories of guilt and shame. Shame is an emotional pattern that can be attributed with a social environment in a variety of ways.

Under the influence of media and the "celebrity culture" (Furedi 2010) Poles became strangers to each other and estranged from their previous national identity, which incidentally became the main enemy. That is how on the Polish way to recovery and normalization the subtle mark between self-criticism and self-hating has been overstepped. Even though in Germany the cleansing of conscience was undergone with the use of high culture (Grass, Sloterdijk), in Poland the celebrity culture took on the leading role. In this media and Facebook culture, all the values and criteria of truth are flexible and sometimes even completely backwards. The judges and juries of this symbolic war pass on their judgments characteristically for low culture, meaning in the form of hate speeches and media lynches.

\section{CONCLUSION}

World War II was a disaster in world history, which resulted in an enormous trauma. The effects of War were so vast and deep that people are dealing with them to this very day. The more we move away from the events that caused this trauma, the less we agree on what these events were, how to interpret them and how to experience them.

The post-war trauma is struggled with on an individual level as well as a national level in a characteristic way of marking the sequence of critical points and the roles that were played out dur- 
ing the conflict, be it the victors or the defeated. Overcoming the post-war trauma is a process of recovery and normalization that on a generational and cultural level is a cyclical process repeated and adjusted to through the reinterpretation of individual and collective identities.

The post-war reconstruction of collective (national) identities even if it starts with the best possible intentions in the long run can lead to distortions of the ultimate facts so big that the processes of recovery and normalization transform into its contradiction. This contradiction is a symbolic war, which can be illustrated by three characteristics. First one is the fact that the attacking side is often times a very aggressive minority, which becomes the "vox populi", contrary to the voice of the majority, which is defensively silent and estranged. Secondly, the attacking minority using hate speech depicts strangers as ones without human traits, demanding their ghettoization, obligatory psychiatric care and penalizing not even any specific actions but potential, imputed intentions. Thirdly, the dominant side in media wars is the one that owns the media, with which it affectively mobilizes the masses. Till this mobilization reaches only the level of symbolism and taboo violation it is still a symbolic war. However when the affective mobilization is joined with a military one then the media become an engine of imitation, thus, leading to a real war (Pinkerton 2012).

\section{REFERENCES}

Bańka, A. Ertelt, B.J. (2011). Transnational vocational counseling. W: S. Kraatz, S, Bernd-Joachim (Eds.), Professionalization of career guidance in Europe. Training, guidance research, service organization and mobility (pp. 137-152). Tübingen: DGVT-Verlag.

Barakat, S., Zyck, S.A. (2009). The evolution of post-conflict recovery. Third World Quarterly, 30, 6, 1069-1086.

Bartky, S.L. (1996). The pedagogy of shame. In: C. Luke (Ed.), Feminisms and pedagogies of everyday life (pp. 225-241). Albany: State University of New York. 
Bahlcke, J., Gawrecki, D., Kaczmarek, R. (2012). Historia Górnego Śląska (A history of Upper Silesia). Katowice: Silesia Progress.

Brague, R.(1992). L'Europe, la voie romaine. Paris: Editions Critérion- Idées.

Finlay, W.M.L. (2005). Pathologizing dissent: Identity politics, Zionism and the 'self-hating Jew'. British Journal of Social Psychology, 44, 201-222.

Fukuyama, F. (1992). The End of History and the Last Man. Free Press.

Furedi, F. (2003). Therapy culture: Cultivating Vulnerability in an Uncertain Age. London: Rutledge.

Furedi, F. (2007). The changing meaning of disaster. Area, 39, 4, 482-489.

Furedi, F. (2010). Celebrity culture. Society, 47, 6, 493-497.

Grass, G. (2007). Przy obieraniu cebuli (Peeling the onion). Gdańsk: Wydawnictwo Oskar.

Gross, T. (2001). Neighbors: The destruction of the Jewish community in Jedwabne, Poland, Princeton University Press.

Harpham, G.G. (2002). Symbolic Terror, Critical Inquiry, 28, 2, 573-579.

Hollander, P. (1992). Anti-Americanism: Critiques at home and abroad 1965-1990.

New York: Oxford University Press,

Hollander, P. (2002) Discontents: Postmodern E Postcommunist. New Brunswick, NJ.: Transaction Publishers.

Illouz, E. (2007). Cold intimaces: The making of emotional capitalism. Cambriodge: Polity Press.

Jendroszyk, P. (2012). Brunatna przeszłość wypędzonych, Rzeczpospolita, 21 listopada, s.10.

Judt, T. (2008). Powojnie. Historia Europy od 1945. Poznań: Rebis. (Postwar: A History of Europe Since 1945. Penguin Press, 2005).

Judt, T. (2012). Wielkie złudzenie. Esej o Europie. Poznań: Rebis

Kersten, R. (2009). The intellectual culture of postwar Japan and the 1968-1969 University of Tokyo Struggles: Repositioning the Self in Postwar Thought. Social Science Japan Journal, 12, 2, 227-245.

Legutko, R. (2008). Esej o duszy polskiej. (An essay about the Polish soul). Kraków: Ośrodek Myśli Politycznej.

Lewin, K. (1940/1997). Self-hatred among Jews. In: Lewin, K: Resolving social conflicts and field theory in social science.Washington, DC, US: American Psychological Association, 133-142.

Lukas, R.C. (2012). Zapomniany holokaust. Polacy pod okupacją niemiecką 1939-1944. (The Forgotten Holocaust: The Poles Under German Occupation, 19391944. Poznań: Rebis.

Macdonald, S. (2009). Reassembling Nuremberg reassembling heritage. Journal of Cultural Economy, 2, 1/2, 117-134. 
Mannet, P. (2008). Racja narodów. Elbląg: Sprawy Polityczne.

Melendy, B. D. (2006). Narratives, festivals, and reinvention: Defining the German postwar homeland in Waldkraiburg. Journal of Popular Culture. 39, 6, 1049-1076.

Monteith, M., Winters, J. (2002). Why we hate. Psychology Today, 35, 3, 44. 8p.

Oliva, G. (2006). Si ammazza troppo poco. I crimini di guerra italiani 1940-43. Milano: Mondadori.

Pickren,W. E. (2012).Psychologists, race, and housing in postwar America. Journal of Social Issues. 67, 1, 27-41.

Pinkerton, P. (2012). Resisting memory: The politics of memorialisation in postconflict Northern Ireland. British Journal of Politics \& International Relations. $14,1,131-152$.

Piskorski, J. M. (Ed.) (2012). Wojna, pamięć, tożsamość (War, memory, and identity). Warszawa: Bellona

Robins, R.S., Post, J.M (1999). Paranoja polityczna. Psychopatologia nienawiści. Warszawa: KiW. (English edition: Political paranoia. The psychopolitics of hatred).

Robinson, M.D., Wilkowski, B.N. (2006). Loving, hating, vacillating: Agreeableness, implicit self-esteem, and neurotic conflict. Journal of Personality, 74, 4, 935-977.

Rodrik, D. (2011). The globalization paradox. New York: Norton \& Company, Inc.

Sakai, T. (2009). Trans-generational memory: Narratives of world wars in postconflict Northern Ireland. Sociological Research Online, 14, 5,1-14.

Seeman, M. (1971).The urbanalienations: Some dubious theses from Marx to Marcuse. Journal of Personality and Social Psychology, 19,2, 135-143.

Segev T. (2012). Siódmy million. Izrael - piętno Zagłady, Warszawa: Wydawnictwo Naukowe PWN.

Sloterdijk, P. (2009). Theory of the post-war periods: Observations on Franco-German relations since 1945. Wien: Springer.

Sloterdijk, P. (2008). Krytyka cynicznego rozumu. Wrocław: Wydawnictwo DSW. (Critique of Cynical Reason, translation by Michael Eldred; foreword by Andreas Huyssen, Minneapolis, University of Minnesota Press, 1988).

Szatkowski, W. (2012). Goralenfolk. Historia zdrady. Zakopane: Kanon.

Wheen, F. (2009). Strange days indeed: The golden age of paranoia. London: Fourth Estate

Wright, S.C., Taylor, D.M and Moghaddam, F.M. (1990). Responding to membership in a disadvantaged group: From acceptance to collective protest, Journal of Personality and Social Psychology, 58, 6, 994-1003.

Zaremba, M. (2012). Wielka trwoga. Polska 1944-1947. Kraków: Znak. 